\title{
Finansiranje istraživanja i razvoja u svijetu, jugoistočnoj Evropi i Bosni i Hercegovini
}

\author{
Fikret Čaušević
}

Sažetak: Ovaj rad analizira finansiranje naučnog i istraživačkog rada, počevši od globalnog i regionalnog konteksta, završavajući sa specifičnostima i ulaganjima za ove namjene u Bosni i Hercegovini. U prvom dijelu analiziran je globalni kontekst, koji sadrži i analizu deset zemalja s najvećim ulaganjima za ove namjene, kao i strukturom izvora finansiranja po sektorima. U skladu s posljednjim dostupnim podacima UNESCO-a, koji se u vrijeme pisanja ovog rada na globalnom nivou odnose na 2018. godinu, vodeće zemlje po relativnom ulaganju u istraživanje i razvoj bile su Južna Koreja i Japan, dok po apsolutnim iznosima dva vodeća mjesta zauzimaju SAD i Kina. Drugi dio ovog rada fokusiran je na uporednu analizu ulaganja u istraživanje i razvoj u zemljama centralne i jugoistočne Evrope. U ovoj grupi zemalja dominira Slovenija, koju slijede Republika Češka i Mađarska. Treći dio je u cijelosti posvećen specifičnostima Bosne i Hercegovine, kao i nekim od ključnih faktora vrlo niskog nivoa ulaganja za istraživanje i razvoj u ovoj zemlji. U četvrtom dijelu prezentirani su neki od uspješnih primjera bosanskohercegovačkih kompanija po ključnim industrijskim granama u kojima je Bosna i Hercegovina ostvarila natprosječne rezultate u poređenju sa zemljama jugoistočne Evrope, u kontekstu niskih ulaganja u istraživanje i razvoj, s jedne strane, i vrlo dobrih izvoznih rezultata mjerenih Indeksom ekonomske kompleksnosti i Indeksom kompleksnosti proizvoda, s druge strane.

Ključne riječi: istraživanje i razvoj (R\&D), finansiranje, svijet, jugoistočna Evropa, Bosna i Hercegovina, Indeks ekonomske kompleksnosti

JEL klasifikacija: O30, O39

\section{Globalni kontekst}

U skladu s podacima UNESCO-vog Instituta za statistiku (UIS), ukupni izdaci za istraživanje i razvoj (R\&D) u svijetu za 2018. (posljednji dostupni podaci) iznosili su 1.700 milijardi USD po paritetu kupovne moći (\$PPP). Učešće zbirnih ulaganja u R\&D deset zemalja koje najviše ulažu u istraživanje i razvoj (Tabela 1) $u$ apsolutnim iznosima u odnosu na ukupno ulaganje $u R \& D$ u svijetu bilo je 84,5\%. Iste godine zbirni BDP tih deset zemalja izražen u \$PPP iznosio je 76.860 milijardi, što je činilo 59,5\% ukupnog svjetskog BDP-a iskazanog u \$PPP ${ }^{1}$.

\footnotetext{
* Dopisni član Akademije nauka i umjetnosti Bosne i Hercegovine. Profesor na Fakultetu za ekonomiju i biznis Univerziteta u Sarajevu. E-mail: fikret.causevic@efsa.unsa.ba

${ }^{1}$ Dostupno na: https://data.worldbank.org/indicator/NY.GDP.MKTP.PP.CD
} 
Drugim riječima, učešće ukupne vrijednosti sredstava uloženih u istraživanje $i$ razvoj 2018. u SAD, Kini, Japanu, Njemačkoj, Južnoj Koreji, Francuskoj, Indiji, Velikoj Britaniji, Brazilu i Ruskoj Federaciji, iskazano u procentima prema zbirnom BDP-u ovih zemalja (u \$PPP) bilo je za 1,5 puta veće od svjetskog prosjeka.

Tabela 1. Deset vodećih zemalja po apsolutnom ulaganju u $R \& D-2018$.

\begin{tabular}{lcccc}
\hline \multirow{2}{*}{ Zemlja } & $\begin{array}{c}\text { Ukupna ulaganja u R\&D } \\
\text { u milijardama \$ PPP }\end{array}$ & \multicolumn{3}{c}{ Učešće sektora u ukupnim ulaganjima (u \%) } \\
\cline { 3 - 5 } & 476,5 & Poslovni sektor & Vlada & Univerziteti \\
\hline 1. SAD & 372,3 & 71,5 & 11,4 & 13,1 \\
\hline 2. Kina & 169,6 & 77,3 & 15,8 & 6,9 \\
\hline 3. Japan & 109,6 & 77,7 & 8,3 & 12,6 \\
\hline 4. Njemačka & 73,1 & 67,6 & 14,6 & 17,7 \\
\hline 5. Južna Koreja & 60,6 & 78,2 & 11,2 & 9,0 \\
\hline 6. Francuska & 51,7 & 63,7 & 12,7 & 22,3 \\
\hline 7. Indija & 43,8 & 37,1 & 56,5 & 6,4 \\
\hline 8. V. Britanija & 42,2 & 65,1 & 7,3 & 25,8 \\
\hline 9. Brazil & 40,3 & --- & --- & --- \\
\hline 10. Ruska Federacija & 59,6 & 30,5 & 9,9 \\
\hline
\end{tabular}

Izvor: UIS - UNESCO Institute for Statistics, dostupno na: http://uis.unesco.org/apps/visualisations/research-and-developmentspending/ - pristupljeno 10. 1. 2021.

Učešće SAD, kao vodeće ekonomske i tehnološke sile u svijetu, u ukupnim svjetskim izdacima za R\&D bilo je znatno veće u odnosu na učešće iste zemlje u svjetskom BDP-u (28\% prema 15,9\%). I Kina je, kao druga je najveća svjetska ekonomija, imala značajno veće učešće u izdacima za R\&D u odnosu na učešće u svjetskom BDP-u (21,9\% prema 16,8\% $\left.{ }^{2}\right)$. Međutim, najveće razlike između učešća u ukupnim R\&D izdacima i učešća u svjetskom BDP-u evidentirana su u Japanu i Južnoj Koreji. Učešća ove dvije zemlje u svjetskim izdacima za R\&D 2018. bila su 2,5 puta veća od njihovog učešća u svjetskom BDP-u - Japana 10\% prema 4\%, i Južne Koreje 4,3\% u odnosu na 1,7\%. Ove dvije zemlje su, istovremeno, i dvije vodeće zemlje u svijetu po relativnom ulaganju u R\&D, odnosno po ulaganju u R\&D u procentima BDP (Tabela 2).

Najveći generatori ulaganja u R\&D u Južnoj Koreji, Japanu, Kini i SAD su kompanije iz poslovnog sektora (u prosjeku za ove četiri zemlje približno

\footnotetext{
${ }^{2}$ Kina je 2018. po učešću u svjetskom BDP iskazanom u \$PPP bila najveća svjetska ekonomija. Dakle, da bismo otklonili zabunu koja može proisteći iz navedenih učešća u svjetskom BDP koji se odnose na SAD $(15,9 \%)$ i Kinu $(16,8 \%)$ ta učešća su izvedena iz vrijednosti BDP iskazanog $\mathrm{u}$ američkim dolarima po paritetu kupovne moći. BDP dvije navedene zemlje izražen u tekućim dolarima i tekućim cijenama za 2018. pokazuje da su SAD najveća svjetska ekonomija (s približnim učešćem 21,2\%), a Kina druga najveća ekonomija (s približnim učešćem od 14,3\% u 2018).
} 
tri četvrtine ukupnih ulaganja), dok je najveće učešće vlade u finansiranju R\&D od deset vodećih zemalja zabilježeno u Indiji (56,5\%). Vodeće dvije zemlje po učešćima univerziteta u izdacima za R\&D bile su Velika Britanija i Francuska. Prema posljednjim dostupnim podacima (2019) deset vodećih svjetskih kompanija po ulaganju u R\&D bile su: Samsung (J. Koreja), Alphabet (SAD), Volkswagen (Njemačka), Microsoft (SAD), Huawei (Kina), Intel (SAD), Apple (SAD), Roche (Švicarska), Johnson\&Johnson (SAD) i Daimler (Njemačka) $)^{3}$. Ukupan iznos koji su ovih deset kompanija uložile u R\&D bio je \$122,2 milijarde (USD iz 2019). Ovaj iznos približno je jednak BDP koji su 2019. zajedno generirale Slovenija, Bosna i Hercegovina, i Srbija. Također, to je iznos koji predstavlja gotovo četvrtinu BDP-a koji su generirale sve zemlje koje pripadaju grupi zemalja niskog dohotka (28 zemalja) ${ }^{4}$.

$\mathrm{Na}$ listi deset vodećih zemalja po relativnom ulaganju u R\&D (Tabela 2), odnosno izdacima za R\&D u procentima BDP-a, iz grupe deset najvećih ulagača u R\&D u apsolutnim iznosima (Tabela 1) nalaze se Južna Koreja, Japan, Njemačka i SAD. Osim ove četiri zemlje u grupi deset najvećih ulagača u R\&D nalaze se i sljedeće zemlje: Finska, Švicarska, Švedska, Austrija, Danska i Belgija. Tabela 2 sadrži i jedanaestu zemlju - Sloveniju, koja je po ulaganju u R\&D u procentima BDP-a odmah uz Belgiju, pri čemu Belgija ima veći broj istraživača na milion stanovnika.

Tabela 2. Jedanaest vodećih zemalja po relativnom ulaganju u $R \& D-2018$.

\begin{tabular}{lcc}
\hline Zemlja & Izdaci za R\&D u \% BDP & Broj istraživača na milion stanovnika \\
\hline 1. Južna Koreja & 4,3 & 6826 \\
\hline 2. Japan & 3,4 & 5328 \\
\hline 3. Finska & 3,2 & 7009 \\
\hline 4. Švicarska & 3,2 & 4468 \\
\hline 5. Švedska & 3,1 & 6875 \\
\hline 6. Austrija & 3,1 & 4947 \\
\hline 7. Danska & 2,9 & 7310 \\
\hline 8. Njemačka & 2,9 & 4320 \\
\hline 9. SAD & 2,7 & 4205 \\
\hline 10. Belgija & 2,4 & 4528 \\
\hline 11. Slovenija & 2,4 & 4147 \\
\hline
\end{tabular}

Izvor: UIS - UNESCO Institute for Statistics, dostupno na: http://uis.unesco.org/apps/visualisations/research-and-developmentspending/ - pristupljeno 26. 12. 2020.

\footnotetext{
${ }^{3}$ Dostupno na: https://spendmenot.com/blog/top-rd-spenders/ (pristupljeno 26. 12. 2020)

${ }^{4}$ Radi upoređivanja konsultovati podatke o BDP-u na web stranici Svjetske banke: https:// data.worldbank.org/indicator/NY.GDP.MKTP.CD (pristupljeno 26. 12. 2020)
} 
Budući da je svjetski prosjek ulaganja u R\&D (u procentima BDP) 1,35\% podaci iz Tabele 2 pokazuju da Južna Koreja izdvaja trostruko više u odnosu na svjetski prosjek, dok su relativna ulaganja SAD u R\&D dvostruko veća od svjetskog prosjeka. Prema broju istraživača na milion stanovnika vodeća zemlja svijeta je Danska, koju slijede Finska, Švedska i Južna Koreja. Slovenija, kao vodeća zemlja u tranziciji po visini BDP po stanovniku, kao i prva tranzicijska zemlja koja je postala članica euro-zone, prednjači i po ulaganju u R\&D.

\section{Regionalni kontekst: zemlje centralne i jugoistočne Evrope}

Grupu zemalja centralne i jugoistočne Evrope predvodi, dakle, Slovenija s 1,8 puta većim ulaganjima u R\&D u odnosu na svjetski prosjek, dok je Republika Češka na drugom mjestu s približno 1,5 puta većim ulaganjima za ove namjene u odnosu na svjetski prosjek. Trećerangirana Mađarska je na nivou svjetskog prosjeka, a grupu zemalja čija su ulaganja u R\&D ispod polovice svjetskog prosjeka predvodi Srbija. Rangiranje zemalja po broju istraživača na milion stanovnika, za ovu grupu zemalja, pokazuje da Slovenija ima 14 puta više istraživača na milion stanovnika u odnosu na Bosnu i Hercegovinu (BiH), a 4,5 puta više u odnosu na Rumuniju.

Tabela 3. Zemlje centralne i jugoistočne Evrope po relativnom ulaganju u R\&D - 2018.

\begin{tabular}{lcc}
\hline Zemlja & Izdaci za R\&D u \% BDP & Broj istraživača na milion stanovnika \\
\hline 1. Slovenija & 2,4 & 4147 \\
\hline 2. Češka Republika & 2,0 & 3402 \\
\hline 3. Mađarska & 1,4 & 2673 \\
\hline 4. Slovačka & 0,9 & 2715 \\
\hline 5. Poljska & 0,9 & 2064 \\
\hline 6. Bugarska & 0,8 & 1821 \\
\hline 7. Hrvatska & 0,8 & 1437 \\
\hline 8. Srbija & 0,7 & 1830 \\
\hline 9. Rumunija & 0,6 & 903 \\
\hline 10. Sjeverna Makedonija & 0,5 & 837 \\
\hline 11. Crna Gora & 0,4 & 671 \\
\hline 12. Bosna i Hercegovina & 0,3 & 292 \\
\hline 13. Albanija & 0,2 & 155 \\
\hline
\end{tabular}

Izvor: UIS - UNESCO Institute for Statistics, dostupno na: http://uis.unesco.org/apps/visualisations/research-and-developmentspending/ - pristupljeno 26. 12. 2020. 
Rangiranje zemalja centralne Evrope i bivše SFRJ po ukupnim ulaganjima u R\&D, izraženih u \$PPP, na prvo mjesto dovodi najmnogoljudniju zemlju ova dva dijela Evropa - Poljsku (Tabela 4). Ukupna ulaganja Poljske u R\&D 2018. bila su približno šest puta veća u odnosu na Sloveniju. Međutim, Poljska ima 19 puta više stanovnika od Slovenije, pa je razlika po ulaganju u R\&D na per capita osnovi znatno u korist Slovenije. Naime, Slovenija po stanovniku ulaže 3,1 puta više u odnosu na Poljsku (753 naspram 241 u \$PPP). Grupu zemalja jugoistočne Evrope koje ulažu ispod polovice svjetskog prosjeka predvodi, kako je već navedeno, Srbija (vidi Tabelu 3). Ukupna ulaganja Srbije u R\&D na per capita osnovi u 2018. iznosila su \$108 (PPP). Srbija je u poređenju s Hrvatskom uložila 35\% manje, a u poređenju sa Rumunijom $48 \%$ više finansijskih sredstava za ove namjene. S druge strane, Srbija je u odnosu na BiH i Crnu Goru uložila za 3,1 odnosno 2 puta više sredstava respektivno (po stanovniku).

Tabela 4. Zemlje centralne Evrope i bivše SFRJ po apsolutnoj vrijednosti i strukturi ulaganja $u R \& D-2018$.

\begin{tabular}{lllll}
\hline \multirow{2}{*}{ Zemlja } & \multirow{2}{*}{$\begin{array}{l}\text { Ukupna ulaganja u R\&D } \\
\text { u milionima \$ PPP }\end{array}$} & \multicolumn{2}{l}{ Učeš́e sektora u ukupnim ulaganjima (u \%) } \\
\cline { 3 - 5 } & 9.149 & Poslovni sektor & Vlada & Univerziteti \\
\hline 1. Poljska & 46,6 & 23,9 & 29,2 \\
\hline 2. Češka R. & 6.699 & 55,2 & 19,0 & 25,4 \\
\hline 3. Mađarska & 3.408 & 71,5 & 13,7 & 13,5 \\
\hline 4. Slovenija & 1.506 & 77,4 & 12,2 & 10,4 \\
\hline 5. Slovačka & 1.380 & 36,8 & 28,3 & 34,4 \\
\hline 6. Srbija & 756 & 29,6 & 24,5 & 45,9 \\
\hline 7. Hrvatska & 732 & 48,2 & 26,1 & 25,7 \\
\hline 8. S. Makedonija & 143 & 10,5 & 15,4 & 73,4 \\
\hline 9. BiH & 102 & 19,6 & 19,0 & 60,4 \\
\hline 10. C. Gora & 35 & 38,3 & 21,3 & 37,5 \\
\hline
\end{tabular}

Izvor: UIS - UNESCO Institute for Statistics, dostupno na: http://uis.unesco.org/apps/visualisations/research-and-developmentspending/ - pristupljeno 26. 12. 2020.

Međutim, poređenja izdataka za R\&D u zemljama centralne i jugoistočne Evrope neophodno je analizirati i u kontekstu ukupne javne zaduženosti, javne zaduženosti po stanovniku, bruto domaćih proizvoda ovih zemalja u ukupnom iznosu i po stanovniku, kao i polaznih osnova u procesu tranzicije, budući da su ove varijable imale, i imaju i dalje, veliki utjecaj na finansijske kapacitete zemalja za finansiranje po svim osnovama, uključujući i mogućnosti finansiranja R\&D. Slovenija je jedina zemlja bivše SFRJ koja je u cijelosti bila isključena iz ratnih sukoba tokom raspada te zemlje. U skladu s takvom 
pozicijom ova zemlja nije imala ratnih šteta, niti je prekidala proizvodnju tokom posljednje decenije prošlog vijeka. Gubici BiH u ljudskom kapitalu iskazani brojem ubijenih osoba četiri puta su veći nego zbirni gubici svih ostalih članica bivše SFRJ zajedno ${ }^{5}$. Nadalje, izgubljeni BDP BiH u periodu 1992-1995, usljed nemogućnosti proizvodnje, približno je jednak trostrukom BDP BiH iz 1990. BDP BiH je te godine iznosio približno DEM17 milijardi odnosno \$10,7 milijardi prema podacima Saveznog zavoda za statistiku SFRJ iz $1991^{6}$. Dakle, izgubljeni BDP tokom rata za nezavisnost (1992-1995) iznosio je \$32 milijarde u dolarima iz 1990. Broj civilnih i vojnih invalida rata u $\mathrm{BiH}$ približno je $270.000^{7}$, što je u posljednjih 25 godina podrazumijevalo fiskalne rashode po ovom osnovu iz dva entitetska budžeta jednake 4,3\% BDP BiH na godišnjoj osnovi. U poređenju s Hrvatskom, kao raspadom SFRJ drugoj najpogođenijoj bivšoj SFRJ republici, ovaj fiskalni rashod je u posljednji četvrt stoljeća u BiH bio približno četiri puta veći u odnosu na Hrvatsku. Sve ostale zemlje u tranziciji nisu bile suočene s ovom vrstom rashoda, što im je davalo znatno povoljniji osnov za strukturiranje budžetskih izdataka, između ostalog i za finansiranje obrazovanja i naučno-istraživačkog rada.

Razlike u BDP-u po stanovniku i javne zaduženosti po stanovniku zemalja centralne i jugoistočne Evrope u odnosu na BiH prezentirane su na Grafikonu 1 za 2018. godinu. Jedine dvije zemlje centralne i jugoistočne Evrope koje su u poređenju sa $\mathrm{BiH}$ imale niže nivoe javne zaduženosti po stanovniku u odnosu na BDP po stanovniku bile su Republika Češka i Bugarska. Sve ostale zemlje centralne i jugoistočne Evrope ostvarile su znatno veće nivoe javne zaduženosti u odnosu na nivoe BDP-a po stanovniku u poređenju sa $\mathrm{BiH}$. To se posebno odnosi na Hrvatsku, Sloveniju, Crnu Goru i Albaniju čiji su nivoi javne zaduženosti za 2,1 puta bili veći od nivoa BDP-a po stanovniku u odnosu na $\mathrm{BiH}$.

\footnotetext{
${ }^{5}$ Dostupno na: https://hr.wikipedia.org/wiki/Raspad_SFRJ

${ }^{6}$ Podatak o BDP-u u USD za 1990. konvertovan po zvaničnom i stabilnom deviznom kursu tadašnjeg jugoslovenskog dinara (YUD) prema njemačkoj marki (DEM) u omjeru 7 YUD za 1 DEM.

${ }^{7}$ Vidjeti procjenu u: Žarko Papić (2008) „Socijalna inkluzija i filozofija razvoja“, u: Papić, Ž, Čaušević, F. (urednici) Ekonomija ubrzanog razvoja, Forum Bosnae 43/08, Međunarodni forum Bosna, Sarajevo, str. 256-283.
} 
Fikret Čaušević: Finansiranje istraživanja i razvoja u svijetu, jugoistočnoj Evropi i Bosni i Hercegovini

Grafikon 1. Nivoi BDP-a po stanovniku i javnog duga po stanovniku zemalja centralne $i$

jugoistočne Evrope u odnosu na Bosnu i Hercegovinu za 2018. godinu

(Bosna i Hercegovina =1,0; za svaku zemlju lijevi stubac označava nivo BDP-a

po stanovniku, dok desni stupac označava nivo javnog duga po stanovniku)

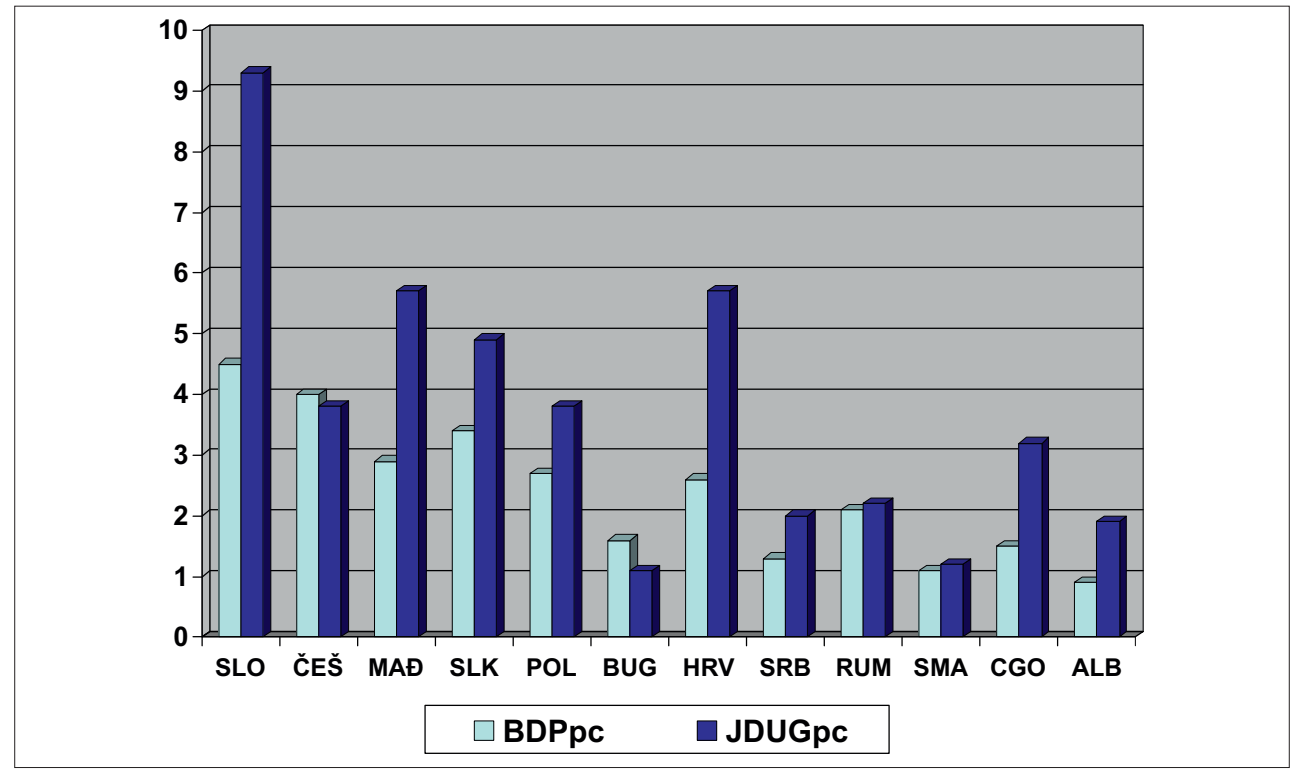

Izvor: konstrukcija autora FČ na osnovu podataka dostupnih na: https://countryeconomy.com/countries/compare/ (pristupljeno 14. 1. 2021)

\section{Finansiranje istraživanja i razvoja u Bosni i Hercegovini}

Finansiranje istraživanja i razvoja u $\mathrm{BiH}$, od njenog osamostaljenja i potpisivanja Pariškog mirovnog sporazuma, bilo je neposredna posljedica administrativne strukture i, posebno, strukture fiskalnog federalizma definisanog i izvedenog iz mirovnih sporazuma i ugovora u Dejtonu i Parizu (novembar/ decembar 1995). Nakon potpisivanja Pariškog mirovnog ugovora (14. 12. 1995), potvrđeno je formalno članstvo $\mathrm{BiH}$ u Međunarodnom monetarnom od 14. 12. 1992, pa su time stvoreni preduslovi da BiH postane članica Grupacije Svjetske banke (23. 3. 1996. čime je ,aktivirano" formalno članstvo od 25. 2. 1993). Osam dana nakon prijema BiH u članstvo Svjetske banke započet je Program prioritetne obnove i rekonstrukcije $\mathrm{BiH}$, koji je trajao četiri godine. Tokom 1996, kao integralni dio paketa administrativnog restrukturiranja BiH, definisana je struktura fiskalnog federalizma i, u skladu s tom strukturom, ovlasti i odgovornosti različitih nivoa vlasti za finansiranje sva tri nivoa obrazovanja, nauke, naučno-istraživačkog rada i kulture. 
Posljedica različite administrativne strukture dva bosanskohercegovačka entiteta bila je i različita nadležnost entitetskih nivoa u finansiranju obrazovanja i naučno-istraživačkog rada. U Federaciji $\mathrm{BiH}(\mathrm{FBiH})$ osnovni izvor finansiranja obrazovanja i nauke u prethodnih 25 godina bili su (i ostali) kantonalni budžeti. Iz budžeta kantona, dakle, finansirana su sva tri nivoa obrazovanja, te dio naučno-istraživačkih projekata. U finansiranju naučnoistraživačkih projekata udio je imao i entitetski nivo vlasti (FBiH). Za razliku od FBiH, u Republici Srpskoj (RS) ključnu odgovornost za finansiranje obrazovanja i naučno-istraživačkog rada ima entitetska vlada, u saradnji s opštinskim/gradskim vlastima u ovom dijelu BiH. U Distriktu Brčko sve nivoe javnog obrazovanja kao i naučno-istraživački rad finansira Budžet Distrikta.

Prema podacima Federalnog zavoda za statistiku (FZS) u periodu 20162018. prosječan (godišnji) broj naučno-istraživačkih projekata realiziran na univerzitetima bio je 37 (bez podatka za RS). ${ }^{8}$ Od tog broja, najveći procenat finansiranih projekata bili su oni vrijednosti do $100.000 \mathrm{KM}$ (ukupno 20). Državni nivo vlasti finansirao je u prosjeku 4 ovakva projekta, kantonalni nivo (u FBiH), također, 4 projekta do navedene vrijednosti, dok su u prosjeku po dva projekta finansirali domaće i inostrane nevladine organizacije i zadužbine/fondacije. Od naučno-istraživačkih projekata vrijednosti 100.000 $300.000 \mathrm{KM}$, po tri projekta su finansirana iz Budžeta FBiH i finansijskih sredstava međunarodnih organizacija. Prosječan broj naučno-istraživačkih projekata vrijednosti 300.000-500.000 KM u navedenom periodu bio je dva, od kojih je po jedan finansiran sredstvima $\mathrm{FBiH}$ i međunarodnih organizacija. U prosjeku su tri projekta vrijednosti iznad 500.000 KM bila finansirana u navedene tri godine, a po jedan od ta tri projekta finansirani su iz Budžeta $\mathrm{FBiH}$, kantona (KS), te međunarodnih fondova. Od ukupno 37 projekata svake godine, 31 je realiziran na javnim univerzitetima dok ih je 6 realizirano na privatnim univerzitetima.

U navedenom istraživanju Federalnog zavoda za statistiku kontaktirano je 39 instituta koji su bili registrovani za naučno-istraživački rad. Od tog broja odgovore na postavljena pitanja u Anketi FZS dalo je 18 instituta. Od ukupno 410 zaposlenih na ovih 18 instituta, 134 zaposlenika su bili istraživači. U periodu 2016-2018, ovi instituti su realizirali ukupno 209 projekata (godišnje približno 70). Od 209 projekata najveći broj se odnosio na konsultantske usluge/projekte - ukupno 103. Najznačajniji projekti, sa stanovišta razvoja izvozne konkurentnosti bh. kompanija kao i sposobnosti supstitucije uvoza

\footnotetext{
${ }^{8}$ Akademija nauka i umjetnosti $\mathrm{BiH}$, „Harmonizacija sistema nauke u Bosni i Hercegovini“ - Federalni zavod za statistiku, „Rezultati statističkog istraživanja“, Sarajevo, 2020, str. 19.
} 
domaćom proizvodnjom kvalitetnih proizvoda, su projekti koji su se odnosili na razvojna i primijenjena istraživanja, uključujući i unapređenje postojeće tehnologije. U ovoj grupi projekata u navedene tri godine u dijelu anketiranih instituta realizirana su 52 projekta. U Anketi FZS nisu navedeni iznosi, odnosno vrijednosti ovih projekata.

Nisku vrijednost ulaganja u naučno-istraživački rad u BiH zorno odražava i dokument koji je pripremila Vlada RS odnosno nadležno ministarstvo Ministarstvo za naučnotehnološki razvoj, visoko obrazovanje i informaciono društvo. U dokumentu naslovljenom - „Mapa puta istraživačkih infrastruktura u Republici Srpskoj (Bosna i Hercegovina) - Mapa puta istraživačkih infrastruktura u Republici Srpskoj ${ }^{\text {} 99}$ navedeni su i podaci o ulaganju u opremu. Dakle, u skladu s podacima prezentiranim u ovom dokumentu ukupna vrijednost finansijskih sredstava koja su transferisana iz Budžeta RS za opremu u 16 istraživačkih institucija (instituti i dijelovi univerziteta odnosno istraživački odjeli fakulteta u RS) za period 2010-2018. iznosila je 1.212.600 KM. Prosječan godišnji iznos sredstava uloženih za naučnoistraživačku infrastrukturu (opremu) u navedenom periodu iznosio je, dakle, za svih 16 institucija 134.733 KM, odnosno 8.420 KM godišnje po instituciji ${ }^{10}$.

Vijeće ministara BiH je u septembru 2016. pripremilo dokument posvećen strateškim pravcima razvoja nauke $\mathrm{u} \mathrm{BiH}^{11}$. $\mathrm{U}$ dijelu ovog dokumenta koji se odnosi na finansiranje naučnog i istraživačkog rada, u periodu 2017-2020, planirano je povećanje ulaganja za ove svrhe sa 101,2 na 189,6 miliona KM, te na 268,2 miliona KM u 2022. Planska učešća dva bosanskohercegovačka entiteta - FBiH i RS, približno su određena učešćima ova dva dijela $\mathrm{BiH}$ u stvaranju BDP-a 66,1\% odnosno 32,9\% respektivno. Preostalo učešće od $1 \%$ odnosi se na Distrikt Brčko. U skladu s, na ovaj način, planiranim učešćima u ukupnom finansiranju naučno-istraživačkog rada u BiH, vrijednost ulaganja bi u FBiH trebala porasti sa 66,9 na 177,4 miliona KM, a u RS sa 33,3 na 88,1 milion KM u periodu 2017-2022. Povećanje ulaganja u naučno-istraživački rad iskazano u procentima BDP-a u BiH za navedeni period

\footnotetext{
${ }^{9}$ Dokument dostupan na sljedećoj web stranici: https://www.vladars.net/sr-SP-Cyr1/Vlada/ Ministarstva/mnk/Documents/RIRS-RoadMap-SR.PDF

${ }^{10}$ Izvor: Ibid, str. 13. Ukupni podaci za cijeli period (2010-2018) i na godišnjem nivou navedeni u tekstu preračunati su na osnovu podataka prezentiranih u Tabeli 1 na str.13.

${ }^{11}$ Vijeće ministara Bosne i Hercegovine. „Strategija razvoja nauke u Bosni i Hercegovini - Revidirani dokument“, Sarajevo, septembar, 2016. Dokument dostupan na sljedećoj web stranici: https://ekonsultacije.gov.ba/legislativeactivities/details/14-prijedlog-revidiranogdokumenta-strategije
} 
planirano je s $0,35 \%$ (2017) na $0,80 \%(2022)^{12}$. Međutim, ostvarena ulaganja u naučno-istraživački rad u BiH već su 2018. bila niža u odnosu na planirana. Naime, prema podacima UIS-UNESCO-a, koje smo u ovom tekstu već analizirali, ukupna ulaganja 2018. bila su 0,3\% BDP. Krajem 2020. pripremljeni su budžeti oba bh. entiteta za 2021. i prema planskim iznosima sada je već nedvojbeno da tokom 2021. i 2022. ukupna ulaganja u BiH za nauku i istraživanje neće dostići 0,5\% BDP-a, za razliku od planiranih 0,75\% BDP-a u prosjeku za dvije navedene godine.

Jedan od najvećih paradoksa finansiranja naučno-istraživačkog rada, odnosno nauke u poslijeratnoj $\mathrm{BiH}$, bio je (i ostao) finansiranje vodećih naučnih institucija od državnog značaja. Ovakav paradoks je neposredna posljedica političke fragmentiranosti i nespremnosti, odnosno kontinuiranog opstruiranja vlasti (dijela vlasti) na entitetskim i državnom nivou da pristanu na finansiranje naučnih institucija (kao i institucija kulture) od značaja za BiH. U ovom smislu nema ilustrativnijeg primjera od finansijskih izvora iz kojih se finansirala Akademija nauka i umjetnosti Bosne i Hercegovine (ANUBiH) u posljednjih 25 godina. Naime, opstanak ove institucije bio je isključivo moguć zahvaljujući finansiranju iz Budžeta Kantona Sarajevo. Ukupni godišnji prihodi ANUBiH u posljednje četiri godine nisu premašili 1,8 miliona KM, iako su bili u porastu u odnosu na prethodnih dvadeset godina. Tačnije, rekordan ukupan prihod ANUBIH je ostvarila u 2019 - 1,769 miliona KM, dok su planirani prihodi za 2020. u iznosu od 1,639 miliona KM. ${ }^{13}$ Ukupni planirani prihod Hrvatske akademije znanosti i umjetnosti (HAZU) za 2020. iznosi 19,8 miliona KM (tačnije 76,192 miliona kuna ${ }^{14}$ ). Od navedenog iznosa godišnjeg prihoda HAZU-a, prihodi iz Budžeta RH čine $83 \%$.

Češka akademija nauka (CAS), prema Godišnjem izvještaju ove institucije za 2019, imala je ukupno 9672 zaposlenika, od kojih su 3926 bili istraživači, a 2014. zaposlenici s univerzitetskim diplomama u istraživačkim institutima $\mathrm{CAS}^{15}$. Prosječna plata svih 9672 zaposlenika u ovoj instituciji i njenim organizacionim jedinicama bila je iste godine 1.947 \$, dok je prosječna

\footnotetext{
${ }^{12}$ Izvor, Ibid., str. 62.

${ }^{13}$ ANUBiH, ,Izvještaj o radu Akademije nauka i umjetnosti Bosnne i Hercegovine za period od 1. jula 2017. do 31. decembra 2020. godine“, Sarajevo, decembar 2020, str. 32.

${ }^{14}$ Izvor: Hrvatska akademija znanosti i umjetnosti - dostupno na: http://info.hazu.hr/upload/ File/2020/ODLUKE-2020/PRORA\%C4\%8CUN-2021.pdf (pristupljeno 8. 1. 2021)

${ }^{15}$ Izvor: The Czech Academy of Sciences, „2019 Annual Report of the Czech Academy of Sciences“, Prague, 2019, str. 45. Dostupan na: https:/www.avcr.cz/opencms/export/sites/ avcr.cz/.content/galerie-souboru/vyrocni-zpravy/VZ-AV-CR-ENG.pdf
} 
plata istraživača iznosila $2.495 \${ }^{16}$. Prosječna mjesečna naknada akademika u ANUBiH iste godine bila je 385 \$. Radi poređenja, BDP po stanovniku Republike Češke veći je od istog pokazatelja za BiH 300\%, dok su mjesečni prihodi istraživača Češke akademije nauka za $550 \%$ bili veći od mjesečnih primanja akademika ANUBiH. Ukupna finansijska sredstva, odnosno prihodi CAS u 2019. iznosili su 681,1 milion \$, odnosno 15.461,7 miliona CZK ${ }^{17}$.

\section{Ulaganja u istraživačko-razvojni $\operatorname{rad} u \mathrm{BiH}$, konkurentnost i ekonomska kompleksnost}

U ukupnoj vrijednosti ulaganja u istraživanje i razvoj u BiH, koja su prema podacima UIS-UNESCO-a u 2018. godini iznosila 102 miliona \$ (PPP), učešće univerziteta bilo je nešto veće od tri petine, učešće poslovnog sektora jednu petinu, a ostatak (19\%) su bila sredstva koja su finansirale vlade na različitim nivoima vlasti. U poređenju s ostalim zemljama bivše SFRJ, Sjeverna Makedonija i BiH su imale najveća učešća univerziteta u finansiranju naučnog i istraživačkog rada, dok je najveće učešće poslovnog sektora bilo u Sloveniji (iznad 77\%) i Hrvatskoj (približno polovina ukupnih ulaganja). Međutim, iako je učešće poslovnog sektora u finansiranju naučnog i istraživačkog rada u $\mathrm{BiH}$ bilo 19,6\% (2018) poslovni rezultati proistekli iz istraživačkog rada i inovacija bosanskohercegovačkih kompanija u mašinogradnji, automobilskoj industriji, preradi metala i drvnoprerađivačkoj industriji ostvareni u periodu 2015-2020. bili su bolji u poređenju sa zemljama iz okruženja, čija su ulaganja u istraživanje i razvoj bila veća ili znatno veća.

U ovom kontekstu neophodno je razmotriti rangiranje zemalja zapadnog Balkana na osnovu Indeksa ekonomske kompleksnosti i Indeksa kompleksnosti proizvoda kao, u praktičnom smislu, jednog od temeljnih mjerila efekata ulaganja u naučno-istraživački rad, posebno u segmentu primijenjenih istraživanja, na proizvodne i izvozne rezultate zemalja ovog regiona. Prema rangiranju the Observatory of Economic Complexity ${ }^{18} \mathrm{BiH}$ je od 2015. do 2019. poboljšala svoj rang mjeren Indeksom ekonomske kompleksnosti za tri mjesta (sa 44 na 41). U istom periodu Srbija je poboljšala svoj rang za dva mjesta (sa 41 na 39), dok je Hrvatska u navedene četiri godine zadržala isti

\footnotetext{
${ }^{16}$ Izvor: Ibid, str. 45 (vrijednosti iz nacionalne valute preračunate po prosječnom godišnjem kursu za 2019)

${ }^{17}$ Izvor: Ibid, str. 48.

${ }^{18}$ Podaci dostupni na web stranici OEC: https://oec.world/en/rankings/eci/hs6/hs96 i https:// oec.world/en/profile/country/bih
} 
rang (37). Dakle, prema vrijednosti Indeksa ekonomske kompleksnosti, koji proističe iz specijalizacije u proizvodnji i kompleksnosti proizvodnih procesa odnosno relativnog znanja u tim proizvodnjama, razlike $u$ rangiranju ove tri zemlje bivše SFRJ su vrlo male. U odnosu na utrošena sredstva odnosno ulaganja u istraživanje i razvoj, ukupna i na per capita osnovi, ostvareni rezultati $\mathrm{BiH}$ odnosno njenog poslovnog sektora u oblasti prerađivačke industrije su u ovom smislu natprosječni, ne samo u regionu jugoistočne Evrope već i u poređenju sa nekim od zemalja centralne Evrope i južnog dijela EU (Grčka, Portugal, Kipar).

Najkompleksniji proizvodi koje BiH proizvodi i izvozi, rangirani u skladu sa Indeksom kompleksnosti proizvoda koji objavljuje OEC, najvećim su dijelom vezani za metaloprerađivačku djelatnost, proizvodnju mašina i alata, te automobilsku industriju. Preciznije, grupe proizvoda sa najvišim Indeksom kompleksnosti proizvoda su sljedeće:

- proizvodnja vijaka, navrtki, zakovica i podložnih pločica,

- zamjenjivi alati i matrice za ručne i elektro-alate,

- brtve i slični spojevi od metala,

- dijelovi i pribor za mašine i alatne strojeve,

- noževi i sječiva za mašine i uređaje,

- električne mašine i oprema,

- mašine i uređaji,

- vozila i njihovi dijelovi. ${ }^{19}$

Izrazit primjer veoma uspješne i plodonosne saradnje između univerziteta, instituta i poslovnog sektora u kontekstu povećanja konkurentnosti bosanskohercegovačke ekonomije i izvoza zahtjevnih proizvoda, kao i proizvodnje sličnih proizvoda za potrebe domaćih kompanija koje su izvozno orijentisane, predstavlja kompanija „TPS“ (Thermal Process Solutions) doo Zenica. Ova kompanija je u vlasništvu Jusufa Durakovića, profesora koji predaje na Fakultetu za metalurgiju i metale Univerziteta u Zenici. Kompanija TPS je 2019. projektovala i proizvela uređaje koji se koriste za hemijsko-termičku obradu u automobilskoj industriji za najzahtjevnije automobile (Ferrari i Maserati) ${ }^{20}$. TPS je, istovremeno, jedina kompanija koja proizvodi ovakav uređaj na prostoru bivše SFRJ, a ovu mašinu je prodala slovenačkoj kompaniji koja proizvodi dijelove za navedene automobilske marke. Osim ovog uređaja kompanija TPS je, također, proizvela endogenerator za potrebe slovenačkog

\footnotetext{
${ }^{19}$ Izvor: https://oec.world/en/profile/country/bih

${ }^{20}$ Vidjeti na sljedećoj web stranici - https:/www.bljesak.info/gospodarstvo/tvrtke/ZenickiTPS-Proizveli-uredaje-za-obradu-dijelova-za-Ferrari-i-Maserati/290228
} 
partnera, protočnu liniju za pečenje papirne harmonike, kao jednog od ključnih proizvodnih inputa za proizvodnju filtera, za kompaniju „Mann+Hummel BA“ dd Tešanj (automobilska industrija), te komornu peć za cementaciju za kompaniju „SIM Technik“ Kotor Varoš. Ova kompanija je vrlo aktivno sarađivala sa kompanijama NN doo Konjic i Graewe Tadiv Konjic, dva vrlo uspješna bosanskohercegovačka izvoznika.

Kompanija „Procassa-Fischer“ d.o.o. Jelah kod Tešnja, također, pokazuje da su kao rezultat akumuliranog znanja i nadgradnje tog znanja, integriranjem i upotrebom novih tehnologija bh. kompanije uspjele postići odlične rezultate na osnovu vlastitog ulaganja u istraživanje i razvoj u okviru poslovne grupacije čije su članice. Mehmed Husaković, direktor ove kompanije, sa kolegama inžinjerima iz $\mathrm{BiH}$ i poslovnim partnerima iz Njemačke u samo tri godine ostvario je odlične rezultate. Ova kompanija je 2018. proizvela prvu CNC mašinu u BiH, a tokom 2019. i prvu PLC presu. Uprkos činjenici da je 2020. godina bila obilježena Covid-krizom, ova kompanija je promovisala svoj novi proizvod krajem septembra 202021. Taj proizvod je šesto-osovinska CNC mašina $^{22}$. Budući da se radi o proizvodu koji integrira „staru“ s „novom“ ekonomijom, odnosno mašinogradnju s informacionom tehnologijom, taj proizvod je time značajniji za konkurentnost $\mathrm{BiH}$. Novoproizvedena CNC šestoosovinska mašina izvezena je u Njemačku za potrebe njemačke autoindustrije.

Sarajevska kompanija „Dizart“ je krajem decembra 2020. promovisala svoju novu, petoosovinsku CNC mašinu. Kompanija je aplicirala za finansijska sredstva podrške istraživačkim i razvojnim projektima koje finansira USAID WHAM. Ova mašina će služiti za obuku polaznika edukacije, kao i za izradu materijala za evropsko tržište. „Dizart“ ostvaruje uspješnu saradnju s Mašinskim fakultetom Univerziteta u Sarajevu, kao i sa Srednjom tehničkom školom metalskih zanimanja u Sarajevu ${ }^{23}$. Prema riječima direktora, više od tri četvrtine ukupne proizvodnje ova kompanija izvozi na tržišta Engleske, Irske i Australije. „Dizart“ je izrazit primjer male kompanije koja uz skromne finansijske izvore ostvaruje izvanredne rezultate i primjer je odlične saradnje sa Univerzitetom u Sarajevu, odnosno neposredne veze između nauke i prakse.

\footnotetext{
${ }^{21}$ Vidjeti na web stranici „Procassa-Fischer“ - https://www.akta.ba/Firma/procassa-fischerdoo/279490

${ }^{22}$ Dostupno na: https://www.akta.ba/vijesti/novi-uspjeh-bh-pameti-nova-cnc-masina-najveca-na-balkanu/124096

${ }^{23}$ Vidjeti na portalu BiznisInfo - https://www.biznisinfo.ba/sarajevska-kompanija-predstavila-novu-cnc-masinu-vlastite-proizvodnje/
} 
Tokom 2020. godine, jedan od „najneobičnijih“ primjera koji ilustruje fleksibilnost i sposobnost bosanskih kompanija bila je, sredinom decembra, objavljena vijest da je ventilator koji je proizvela TMD Group d.o.o. Gradačac dobio certifikat MD-TEC-a iz Londona ${ }^{24}$. Prototip ovog ventilatora TMD Group je razvila u saradnji sa Univerzitetskim kliničkim centrom u Tuzli. Ova kompanija je u predratnom periodu, tokom sedamdesetih i osamdesetih godina prošlog vijeka, bila integralni dio Famosa iz Sarajeva, za koji je proizvodila dijelove za transportna sredstva i uređaje. Početkom ovog vijeka ova kompanija je privatizirana metodom tenderske privatizacije i ponovo je razvila proizvodnju dijelova za automobilsku industriju (prvu ugradnju), najvećim dijelom za kompanije iz zapadne Evrope. Višedecenijsko iskustvo i tradicija u metaloprerađivačkoj industriji kompanija u BiH, i na primjeru ove kompanije, pokazuje da je uz skromna ulaganja u inovacije moguće postići odlične rezultate i prilagoditi proizvodnju i u proizvodnim granama u kojima uopšte ranije nisu bile prisutne.

Posebno uspješan primjer saradnje između akademskih institucija i industrije u oblasti inovacija i razvoja proizvoda, odnosno industrijskog dizajna u BiH jeste primjer saradnje predavača koji rade na Akademiji likovnih umjetnosti Univerziteta u Sarajevu i kompanija Yield doo Sarajevo i MS\&Wood doo Sarajevo. Kompaniju Yield doo Sarajevo osnovao je Zlatko Tanović 2007, a od 2013. Tanović je započeo intenzivnu saradnju s jednim od najpriznatijih dizajnera u oblasti proizvodnje namještaja iz jugoistočne Evrope Salihom Teskeredžićem ${ }^{25}$, koji predaje na Akademiji likovnih umjetnosti Univerziteta u Sarajevu. Teskeredžić je u okviru kompanije Yield d.o.o. razvio produkt-dizajn brend pod nazivom „Gazzda“. Za svoje proizvode ovaj dizajner je dobio nekoliko prestižnih međunarodnih nagrada za dizajn namještaja. Nataša Perković26 ${ }^{26}$, profesorica koja predaje na Akademiji likovnih umjetnosti Univerziteta u Sarajevu, dizajnirala je stolicu za koju je kompanija „MS\&Wood“ d.o.o. Sarajevo dobila nagradu na sajmu namještaja u Njemačkoj. Na tom istom sajmu komoda proizvedena u „MS\&Wood“ koju je dizajnirao Ado Avdagić ${ }^{27}$ dobila je najprestižniju nagradu - the German

\footnotetext{
${ }^{24}$ Vidjeti na web stranici TMD Group - https://tmd-group.ba/respirator-proizveden-u-gradaccu-certificiran-u-britaniji/

${ }^{25}$ Dostupno na: https://bigsee.eu/salih-teskeredzic-bosnia-and-herzegovina-big-see-visionary-2019/

${ }^{26}$ Dostupno na: https://www.archiproducts.com/en/designers/natasa-perkovic

${ }^{27}$ Vidjeti na: https://www.artisan.ba/en/designers/ado-avdagic
} 
Design Award ${ }^{28}$. Avdo Avdagić i Salih Teskeredžić intenzivno sarađuju i razvijaju nove proizvode u jednoj od najuspješnijih kompanija u oblasti industrije namještaja na području jugoistočne Evrope - kompaniji „Artisan“ doo Tešanj ${ }^{29}$. Na Akademiji likovnih umjetnosti Univerziteta u Sarajevu predaje i Bojan Hadžihalilović, koji je sa svojom kompanijom „Fabrika“ d.o.o. Sarajevo u oblasti grafičkog dizajna u posljednje dvije decenije dostigao regionalnu i evropsku reputaciju.

U oblasti „nove ekonomije“30, „neopipljive ekonomije“ ili ekonomije bazirane na informaciono-komunikacijskim tehnologijama, bosanskohercegovačke kompanije ne zaostaju za kompanijama iz istog sektora sa područja zapadnog Balkana, a neke ne zaostaju ni za IT kompanijama iz centralne i istočne Evrope. Tokom 2019. godine Deloitte Central Europe je objavio svoju listu 50 najbrže rastućih tehnoloških kompanija sa područja centralne i jugoistočne Evrope (po visini stopa rasta ukupnog prihoda). Na toj listi jedina kompanija sa područja zapadnog Balkana bila je bosanskohercegovačka kompanija „Ministry of Programming“ (MP), sa godišnjim rastom prihoda 2019. od $813 \%$. MP je osnovana 2015. a specijalizirala se u razvoju prvoklasnih start-up kompanija iz ovog sektora. Kompanija je, prema navodima Deloittea, razvila prvoklasne usluge i proizvode u razvoju pretraživanja i analize podataka, razvoja društvenih mreža, softvera za razvoj trgovine, kao i softvera za otkrivanje virusa. Tri od trideset pet start-up kompanija u koje je uložila MP kompanija u periodu 2015-2019, Google, McKinsey i Rocket Internet potvrdili su kao strat-up-ove svjetske klase ${ }^{31}$.

Pored „Ministry of Programming“ neke od najznačajnijih kompanija iz IT sektora, koje su višegodišnjim odnosno sada već višedecenijskim ulaganjem $\mathrm{u}$ istraživanje i razvoj postigle regionalnu i evropsku reputaciju su kompanije „Lanaco“ i „BS Telecom Solutions“. „Lanaco“ je 2016. postao prva bh. kompanija u ELITE programu Londonske berze i pozicionirao se među 50 najuspješnijih kompanija u Evropi. Sljedeće (2017) godine ova kompanija je dobila bronzanu medalju u konkurenciji za SAP Quality Award - SAP ERP

\footnotetext{
${ }^{28}$ Dostupno na: https://www.sarajevotimes.com/company-ms-wood-won-2-prestigious-german-design-awards-2018/

29 Vidjeti: https://www.dnb.com/business-directory/company-profiles.artisan_doo_tesanj. f79f8c48dde194e74c0f035898df9cde.html

${ }^{30} \mathrm{Za}$ nedavu diskusiju efekata „new economy“ (oktobar 2020) vidjeti tekst dostupan na Brookings web stranici: https://www.brookings.edu/research/whats-new-about-the-new-economy-it-economic-growth-and-productivity/

${ }^{31}$ Deloitte Central Europe: Deloitte Central Europe, „Deloitte Technology Fast 50 Central Europe“, https://www2.deloitte.com/ce/en/pages/about-deloitte/topics/technology-fast-50.html
} 
za poslovnu transformaciju na području centralne i istočne Evrope ${ }^{32}$. U cilju ubrzavanja ulaganja i razvoja ovog sektora „Lanaco“ je u Banja Luci otvorio Lanaco tehnološki centar (2016.) a sljedeće godine su osnovali „ITivity“ softversku akademiju. „Lanaco“ posluje na području cijele BiH, ima svoje urede u Banja Luci i Sarajevu, i prvoklasni je primjer integrativnog ekonomskog pristupa bosanskohercegovačke, na znanju zasnovane, ekonomije. BS Telecom Solutions je još jedan primjer kompanije iz IT sektora, čije su reference u razvoju IT poslovnih rješenja i veoma uspješni projekti realizirani u Republici Češkoj, Ruskoj Federaciji, Bosni i Hercegovini (u oba bh. entiteta) i, odnedavno, u susjednoj Srbiji pokazali da je kontinuirano ulaganje u znanje i inovativni rad najbolji način za dostizanje evropske reputacije u svijetu savremenog poslovanja. „Infobip BH“ d.o.o. Sarajevo, kompanija-kćerka hrvatske kompanije „Infobip“ iz Vodnjana, jedna je od najuspješnijih IT kompanija u BiH. Ova kompanija je započela realizaciju izgradnje razvojnog kampusa u Sarajevu koji bi trebao biti završen 2022. sa planiranih 500 zaposlenih mladih IT inženjerki i inženjera.

Prema već navedenim podacima u Tabeli 2 (vidjeti drugi dio ovog teksta: „Regionalni kontekst: zemlje centralne i jugoistočne Evrope“) relativni izdaci za R\&D izraženi u procentima BDP-a u 2018. u četiri industrijski najjače ekonomije bivše SFRJ bili su: Slovenija $(2,4)$, Hrvatska $(0,8)$, Srbija $(0,7)$ i $\mathrm{BiH}(0,3)$. U Tabeli 3 prikazali smo učešća tri sektora u finasiranju R\&D. U skladu s tim podacima učešća poslovnog sektora bila su sljedeća: Slovenija (77\%), Hrvatska (48\%), Srbija (30\%) i BiH (20\%). Na osnovu ovih podataka možemo zaključiti da su izdaci poslovnog sektora u navedene četiri zemlje izraženi u procentima BDP-a 2018. bili sljedeći: Slovenija $(1,86)$, Hrvatska $(0,38)$, Srbija $(0,21)$ i BiH $(0,06)$. Dakle, izdaci poslovnog sektora za finansiranje R\&D u Sloveniji bili su 35 puta veći nego u BiH, 8,9 puta veći nego u Srbiji, i 4,9 puta veći nego u Hrvatskoj. Ukupna relativna ulaganja u R\&D u Sloveniji su iste godine bila 8 puta veća nego u BiH, 3,4 puta veća nego u Srbiji, i 3 puta veća nego u Hrvatskoj. Vrlo značajne razlike između ulaganja poslovnog sektora u R\&D između Hrvatske, Srbije i BiH nisu rezultirale velikim razlikama u rangovima Indeksa ekonomske kompleksnosti.

Drugim riječima, efikasnost uloženih sredstava u R\&D i inovacionu aktivnost na kompanijskom nivou pokazuje da su bosanskohercegovačke kompanije sa znatno manjim ulaganjima ostvarile vrlo dobre rezultate, koji dijelom mogu biti objašnjeni sposobnostima menadžera u metaloprerađivačkoj

\footnotetext{
${ }^{32}$ Vidjeti: LANACO web site - https://www.lanaco.com/nasa-prica/
} 
industriji, mašinogradnji, proizvodnji autodijelova, drvnoprerađivačkoj industriji i IT sektoru da uspješno inoviraju i komercijaliziraju svoje proizvode i usluge na osnovu ranije razvijenih višedecenijskih znanja i tradicije u prve četiri spomenute industrije, odnosno na osnovu razmjerno brzog učenja (IT sektor). Jedno od ključnih objašnjenja značajnog postignuća nekoliko desetina bosanskohercegovačkih kompanija, kao i visokog rangiranja BiH po Indeksu ekonomske kompleksnosti (u top 28\% svjetskih ekonomija), uzevši u obzir niska ulaganja u istraživanje i razvoj, sa jedne strane, i efikasnost uloženih sredstava u poslovnom sektoru, sa druge strane, jeste analiza izvora inovativnosti prezentirana u radu Radoševića ${ }^{33}$. Radošević ističe, referirajući se na rad Lorenza i Lundvalla, da se inovativni rad ne dešava samo zahvaljujući ulaganju sredstava u R\&D u javnom sektoru, već da je inovativnost posljedica „doing-using-interacting“ rada, zasnovanog na proizvodnim i poslovnim iskustvima preduzetnika i inovatora. Ovaj aspekt analize inovativnosti i razmjerno visoke proizvodne kompleksnosti bolje objašnjava visoke rangove Srbije, Hrvatske i, posebno, $\mathrm{BiH}$ u odnosu na sama izdvajanja iz javnog sektora za R\&D aktivnosti.

\section{Zaključna razmatranja}

Analiza globalnih i regionalnih iskustava u finansiranju istraživanja i razvoja pokazuje da sve vodeće svjetske ekonomije, kako mjereno po ukupnom BDP-u tako i po BDP-u po stanovniku, imaju veća učešća u ukupnim globalnim izdacima za istraživanje i razvoj u odnosu na učešća tih zemalja u svjetskom BDP-u. Južna Koreja je izrazit primjer male otvorene ekonomije koja je u posljednje tri decenije ostvarila izuzetne tehnološke rezultate i globalnu konkurentnost u nekoliko industrijskih grana. Ova zemlja je dokaz da su ciljana i efikasno kontrolirana namjenska ulaganja u istraživanje i razvoj imala za posljedicu tehnološki proboj na globalnim tržištima. Dvije najveće ekonomije u svijetu po ostvarenom BDP - SAD i Kina su, istovremeno, i najveći ulagači u istraživanje i razvoj u apsolutnim iznosima. Zemlje Skandinavije, kao i vodeće zemlje zapadne Evrope, također, predstavljaju izrazite primjere isplativosti ulaganja $\mathrm{u}$ istraživanje i razvoj, ali i neophodnosti da ta ulaganja budu procentualno veća u odnosu na učešća ovih zemalja u kreiranju svjetskog BDP-a.

\footnotetext{
${ }^{33}$ Slavo Radoševič (2021) „Public R\&D and Science - Industry Links in Economic Development: Implications for Bosnia and Herzegovina“, London, June, članak pripremljen za konferenciju ANUBiH „, u BiH“ u novembru 2021., str. 8-9.
} 
Globalna iskustva i trendove $u$ finansiranju istraživanja i razvoja na području centralne i jugoistočne Evrope najuspješnije je pratila i primijenila Slovenija, kao vodeća zemlja u tranziciji po ostvarenom BDP-u po stanovniku. Ova tranzicijska zemlja, i bivša članica SFRJ, je vodeća po relativnom ulaganju u istraživanje i razvoj ne samo u ovom dijelu svijeta, već je i jedanaesta u svijetu. Odnos Slovenije i njenih kreatora državne i ekonomske politike, kao i strategije razvoja nauke i istraživanja, rezultirao je time da se ova mala zemlja nalazi na dvanaestom mjestu u svijetu po Indeksu ekonomske kompleksnosti, kao i u grupi zemalja sa vrlo visokom vrijednošću Indeksa humanog razvoja. U grupi ostalih zemalja centralne i jugoistočne Evrope najveća ulaganja u istraživanje i razvoj ostvarile su Republika Češka i Mađarska, čije su ekonomije u posljednjih deset godina ostvarile značajne uspjehe.

Osim Slovenije, koja je imala najbolju poziciju tokom raspada bivše SFRJ, budući da nije pretrpjela ratne štete, ostale zemlje bivše SFRJ znatno manje ulažu u istraživanje i razvoj. Hrvatska i Srbija su znatno ispod svjetskog prosjeka po ulaganju za ove svrhe, dok je Bosna i Hercegovina, poslije Albanije, zemlja sa najnižim ulaganjima u istraživanje i razvoj od svih zemalja centralne i jugoistočne Evrope. Vrlo nizak nivo ulaganja u istraživanje i razvoj Bosne i Hercegovine posljedica je jednim dijelom objektivnih faktora, a drugim dijelom izrazito pogrešnog stava vlasti u odnosu na značaj organizovanih ulaganja u istraživanje i razvoj za budući razvoj društva, konkurentnosti i izvozne sposobnosti. Najznačajniji objektivni faktor bitno različite polazne pozicije Bosne i Hercegovine u tranziciji u odnosu na sve ostale tranzicijske zemlje, sa naglaskom na ostale zemlje bivše SFRJ, jeste činjenica da je ova zemlja pretrpjela višestruko veća ratna razaranja (ljudi i oprema) od zbirnih šteta svih ostalih članica bivše SFRJ. Jedna od posljedica su finansijski rashodi budžeta entiteta u $\mathrm{BiH}$ za finansiranje socijalne zaštite civilnih i vojnih žrtava rata četvrestruko veći u odnosu na ostale najpogođenije članice te bivše države.

$\mathrm{S}$ druge strane, ne postoji niti jedan razlog za opravdanje vlasti koje u strukturi raspoloživih i do Covid-krize rastućih poreskih prihoda nisu bile voljne ostvariti ciljeve finansiranja istraživačkog i razvojnog rada koje su same postavile u ključnim razvojnim dokumentima, usvojenim na različitim nivoima vlasti. Jedna od izravnih posljedica takvog odnosa bila je, a i dalje je, odliv najboljih mladih naučnika i istraživača, najvećim dijelom u zemlje zapadne Evrope, Veliku Britaniju i SAD. Premda poslovni sektor u Bosni i Hercegovini nije puno ulagao u istraživanje i razvoj, poslovni rezultati koje su ostvarile kompanije u metaloprerađivačkoj industriji, mašinogradnji, 
automobilskoj i drvnoprerađivačkoj industriji, kao i informaciono-komunikacionim tehnologijama rezultirali su pozicioniranjem Bosne i Hercegovine u grupu najboljih 28\% zemalja po Indeksu ekonomske kompleksnosti. Talenat, proizvodna znanja i sposobnost da zaposlenici u ovim industrijama uče radeći, odnosno da inoviraju, jeste veliki potencijal za značajno poboljšanje kvaliteta života i ekonomije Bosne i Hercegovine, ali ovaj u prethodnom periodu dokazani potencijal može u godinama i decenijama koje slijede relativno brzo prestati biti vodeći faktor iznenađujuće visokog rangiranja bosanskohercegovačke ekonomije po Indeksu ekonomske kompleksnosti u odnosu na ukupna i vrlo skromna ulaganja u istraživanje i razvoj, ukoliko vlasti i kreatori ekonomskih i razvojnih politika u Bosni i Hercegovini radikalno ne promijene stav u odnosu na svjetska iskustva - da je rastuće ulaganje u istraživanje i razvoj vrlo važan preduslov za promjenu kvaliteta života i strukture ekonomije.

\section{Izvori:}

Akademija nauka i umjetnosti Bosne i Hercegovine. „Harmonizacija sistema nauke u Bosni i Hercegovini“ - Federalni zavod za statistiku, „Rezultati statističkog istraživanja“, Sarajevo, 2020.

Akademija nauka i umjetnosti Bosne i Hercegovine. „Izvještaj o radu Akademije nauka i umjetnosti Bosne i Hercegovine za period od 1. jula 2017. do 31. decembra 2020. godine“, Sarajevo, decembar 2020.

Akta.ba - https://www.akta.ba/vijesti/novi-uspjeh-bh-pameti-nova-cnc-masina-najveca-nabalkanu/124096; https://www.akta.ba/Firma/procassa-fischer-doo/279490

Biznis.Info - https://www.biznisinfo.ba/sarajevska-kompanija-predstavila-novu-cnc-masinu-vlastite-proizvodnje/

Bljesak.info - https://www.bljesak.info/gospodarstvo/tvrtke/Zenicki-TPS-Proizveli-uredajeza-obradu-dijelova-za-Ferrari-i-Maserati/290228

CountryEconomy - https://countryeconomy.com/countries/compare/

Deloitte Central Europe, „Deloitte Technology Fast 50 Central Europe“, dostupno na: https://www2.deloitte.com/ce/en/pages/about-deloitte/topics/technology-fast-50.html

Hrvatska akademija znanosti i umjetnosti (HAZU) - „Financijsko-planski dokumenti Akademije“ - dostupno na: http://info.hazu.hr/hr/o-akademiji/fin_planski_dok/

Budžet HAZU: http://info.hazu.hr/upload/File/2020/ODLUKE-2020/PRORA\%C4\%8CUN -2021.pdf

LANACO - https://www.lanaco.com/nasa-prica/

Radošević, Slavo (2021) „Public R\&D and Science - Industry Links in Economic Development: Implications for Bosnia and Herzegovina“, London (June). Članak pripremljen za predstojeću konferenciju ANUBiH ,Sistem naučnog i istraživačkog rada u Bosni i Hercegovini“ - planirani datum održavanja 5. 11. 2021.

SpendMeNot - https://spendmenot.com/blog/top-rd-spenders/

The Brookings Institution - https://www.brookings.edu/research/whats-new-about-the-neweconomy-it-economic-growth-and-productivity/ 
The Czech Academy of Sciences, „2019 Annual Report of the Czech Academy of Sciences“, Prague, 2019, Dostupan na:https://www.avcr.cz/opencms/export/sites/avcr.cz/.content/ galerie-souboru/vyrocni-zpravy/VZ-AV-CR-ENG.pdf

The Observatory of Economic Complexity (OEC) - https://oec.world/en/profile/country/bih

The World Bank Database - https://data.worldbank.org/indicator/NY.GDP.MKTP.CD

TMD Group - https://tmd-group.ba/respirator-proizveden-u-gradaccu-certificiran-u-britaniji/

UIS - UNESCO Institute for Statistics: http://uis.unesco.org/apps/visualisations/researchand-development-spending/

Vijeće ministara Bosne i Hercegovine. „Strategija razvoja nauke u Bosni i Hercegovini - Revidirani dokument", Sarajevo, septembar, 2016. Dokument dostupan na: https://ekonsultacije.gov.ba/legislativeactivities/details/14-prijedlog-revidiranog-dokumenta-strategije

Vlada Republike Srpske - Ministarstvo za naučnotehnološki razvoj, visoko obrazovanje i informaciono društvo, „Mapa puta istraživačkih infrastruktura u Republici Srpskoj (Bosna i Hercegovina) - Mapa puta istraživačkih infrastruktura u Republici Srpskoj“, dostupno na: https://www.vladars.net/sr-SP-Cyrl/Vlada/Ministarstva/mnk/Documents/RIRS-RoadMap-SR.PDF 